\title{
Initial Public Offerings: The Case Of Health Maintenance Organizations (HMOs)
}

Martha Strange, (E-mail: mstrange@moac.morgan.edu), Morgan State University John R. Ezzell, (E-mail: jre@psu.edu), Pennsylvania State University, University Park Aref N. Dajani, (E-mail: adajani@census.gov), University of Maryland

\begin{abstract}
Objective: To determine whether the returns of initial public offerings (IPOs) of HMOs in the days following issue are similar to the return behavior of IPOs in previous studies.

Data Source: The Center for Research in Security Prices (CRSP) tapes compiled by the Graduate School of Business at the University of Chicago provides daily stock prices, holding period returns, and other data pertinent to research in traded securities.

Study Design: The hypothesis to be tested is whether the mean excess return surrounding the offer date is equal to zero. To adjust the initial returns of the IPOs for overall market movements, Standard \& Poor's Composite Index ( $\& \& P$ 500) was selected as the proxy for the market in general. We compute the long-run performance for the HMOs and compare that return to the $S \& P 500$ and the CRSP AMEX/NYSE equally-weighted and value-weighted indices.

Data Collection/Extraction Method: We matched for-profit HMOs listed in the National Directory of Managed \& Integrated Care Organizations to the commitment offerings reported by Securities Data Corporation to the same firms on the daily CRSP tapes. This left 49 firms that went public between 1971 through 1997. The Wharton Research and Data Services External (WRDSX) was used for data extraction and SAS was used for statistical analysis.

Principal Findings: IPOs of HMOs are underpriced and demonstrate abnormal returns. The average initial return on these IPOs is less than that of the average in the United States. On a longrun performance basis, they performed better than the broad market indices.

Conclusions: Returns follow a similar pattern as do IPOs in general except for the long-run performance. This needs further research as well as a comparison of performance before and after going public in cases where accounting data is available.
\end{abstract}

\section{Introduction}

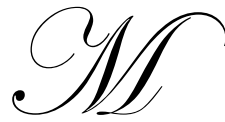

anaged care firms such as health maintenance organizations (HMOs) have received a lot of attention in the last ten years. However, very little empirical financial research has been done in this area in the United States. Many of these firms began as not-for-profit organizations and later converted to for-profit, publicly traded firms. Initial public offerings (IPOs) have traditionally shown abnormal returns soon after the offer date based on studies by Ibbotson, Sindelar, and Ritter (1988) and Loughran and Ritter (1995) and many others. These studies examined companies that were private and later went public. This research replicates the methodology of previous work to some extent using the initial public offerings of HMOs to determine whether their initial returns surrounding the date they go public are in keeping with those of IPOs in general and examine their long-run performance.

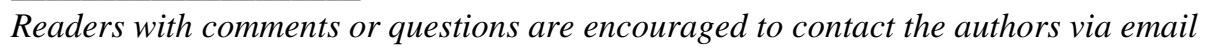


This research examines forty-nine for-profit, publicly traded health maintenance organizations (HMOs) to determine the return received upon going public. It seeks to determine whether there were excess returns and whether those returns were above average as determined by prior research involving initial public offerings (IPOs). It also examines the initial returns to determine whether they are above the historical U.S. average of $15.7 \%$, as reported by Ibbotson, Sindelar, and Ritter (1994, updated for 1999).

\subsection{Motivation and Contribution}

The motivation for this research is the number of for-profit HMO conversions since the early 1980s. Claxton, Feder, Schactman, and Altman (1997) report a 53\% increase in the number of for-profit HMOs between 1981 and 1995. One of the concerns with these conversions was the enormous gain to insiders. Bell, Snyder, and Tien (1997) explain that these gains came, in some cases, to top management and members of the board of directors who agreed to the conversion then became stockholders and employees of the new for-profit company. In other cases, top executives received large severance packages that included stock of the company.

During the early conversion to for-profit status, there were problems with undervaluation of assets. Bell et. al. (1997) give an example of a non-profit HMO whose directors, doctors, and managers purchased the company for $\$ 4$ million and issued themselves stock valued at 33 cents a share. After conversion to a for-profit HMO, they sold a quarter of the company's stock for $\$ 10$ million. During the period of the majority of these conversions, there were concerns from analysts and the public as to the distribution of assets of converting nonprofits. These assets came about as the result of charitable contributions, tax exemption, and volunteer time.

This research seeks to determine the size of the returns to a sample of these HMOs and whether the returns are in keeping with that of the average initial public offering in the United States. Similar empirical research has been conducted to determine the size of returns to various types of corporate securities. Previous research involving HMOs has examined the quality of service and other factors relating to these conversions. Financial research involving HMOs is lacking. This research contributes to the existing literature relating to IPOs in general and HMOs specifically by presenting evidence on returns received by initial public offerings of HMOs following conversion

\subsection{Literature Review}

Research has shown that IPOs are underpriced resulting in excess returns to investors able to purchase at the offer price or shortly after the initial offer. Prior research on IPOs by Chalk and Peavy (1987), Miller and Reilly (1987), Aggarwal and Rivoli (1990), Ibbotson, Sindelar, and Ritter (1988), Ritter (1991), and Rudd (1991) show empirically that investors realize large returns if they are able to acquire stock at the offer price on the first day of trading. Ibbotson et. al. (1994, updated for 1999) show an average return of 15.7 percent in a study using data from 1960 through 1997 . These unusually large returns represent a loss to the company selling the stock. In the case of HMOs, it represents a loss to the public as well.

Many theories have developed to explain the underpricing of IPOs under equilibrium conditions. Some of these include insurance for the invest banker as explained by Beatty and Ritter (1986), Tinic (1988), and Hughes and Thakor (1992). Existence of a principle-agent problem as explained by Baron (1982). Signaling as explained by Allen and Faulhaber (1989), Grinblatt and Hwang (1989), Rock (1986), and Welch (1989) suggests that the large initial returns are a way of attracting uninformed investor. Or, they may be an indication of investment fads as suggested by Aggarwal and Rivoli (1990), Camerer (1989), DeBondt and Thaler (1985), and Shiller (1981). Monopsony power of investment banks is given as a possible explanation by Ritter (1984), and incomplete market by Mauer and Senbet (1992).

Another issue is that related to the pricing of IPOs is their return performance in the period immediately following the offering day called the aftermarket. IPOs generally make good investments if purchased at the offer price and held for one day. Empirical research has shown that their long-run performance is negative in many cases. Muscarella and Vetsuypens (1989), Aggarwal and Rivoli (1990), and Ritter (1991) find that investors in IPOs earn 
negative returns after the first day of trading. Loughran and Ritter (1995) find empirical evidence that IPOs underperform as compared to a group of matching firms on a long-term basis of three to five years.

Our research is similar to prior studies of IPO returns of different types of securities. Loderer, Sheehan, and Kadlec (1991) study preferred stock and found they are not underpriced. In addition, Muscarella (1988), Michaely, and Shaw (1994) found that the mean initial-day returns of IPOs of master limited partnerships are not underpriced. Peavy (1990) found no significant underpricing for closed-end fund IPOs. Wang, Chan, and Gau (1992) found overpricing in the case of real estate investment trust IPOs. Datta, Iskandar-Datta, and Patel (1997) found that IPOs of speculative grade debt are underpriced like equity IPOs, while those rated investment grade are overpriced. Finally, Brav and Gompers (1997) found that the long-run performance of venture-backed IPOs outperform non-venturebacked IPOs using equally weighted returns. This research replicates portions of the Loughran and Ritter (1995) paper for long-run performance, and compares underpricing of IPOs to the average found by Ibbotson, Sindelar, and Ritter (1994, updated).

Loughran and Ritter (1995) examine the returns of 4,753 firms going public in the United States from 1970 through 1990 immediately following the IPO and at one-, three-, and five-year intervals following the IPO offer date. These are compared to 3,702 firms with seasoned (not IPOs) equity offerings to determine the average returns of each and whether the returns to these IPOs are significantly different. They found that both types of new issues had poor long-run performance.

\subsection{Methodology}

\subsection{Sample Selection}

The preliminary sample was obtained by matching for-profit HMOs listed in the National Directory of Managed \& Integrated Care Organizations with the firms listed in the commitment offerings reported by Securities Data Corporation (SDC). To be in the sample, a firm must be incorporated in the U.S. on the offer date, and must be listed on the daily Center for Research in Security Prices (CRSP) tapes. Although there are many for-profit HMOs,

Table 1: Composition of the Sample of IPOs

\begin{tabular}{||cc||}
\hline \multicolumn{2}{|c|}{ IPOs } \\
Year & $\begin{array}{c}\text { Number } \\
\text { of IPOs }\end{array}$ \\
\hline 1971 & 1 \\
1978 & 1 \\
1981 & 1 \\
1983 & 4 \\
1984 & 4 \\
1985 & 1 \\
1986 & 5 \\
1989 & 2 \\
1991 & 8 \\
1992 & 5 \\
1993 & 4 \\
1994 & 3 \\
1995 & 3 \\
1996 & 3 \\
1997 & 4 \\
\hline Total & 49 \\
\hline
\end{tabular}
companies where the stock is privately held and are not publicly traded were not included in the data set. We found 85 publicly traded HMOs. However only 49 HMOs that went public between 1971 through 1997 had an offer price that was available in the SDC database. Table 1 shows the breakdown of the 49 companies by year.

Daily stock prices from the end of the offer day to the end of the eighth day were obtained from the CRSP tapes. To adjust the initial returns of the IPOs for overall market movements, the Standard \& Poor's Composite Index (S\&P 500) was selected as the proxy for the market in general. The Wharton Research and Data Services External (WRDSX) was used for data extraction and the Statistical Analysis System ${ }^{\circledR}$ (SAS) was used to analyze the data.

\subsection{Statistical Tests}

The hypothesis to be tested is whether the mean excess return surrounding the offer date is equal to zero. To adjust the initial returns of the IPOs for overall market movements, Standard \& Poor's Composite Index (S\&P 500) was selected as the proxy for the market in general. This data for each of the eight days was available on the CRSP tapes. We also compute the long-run performance for the HMOs and compare that return to benchmarks such as the S\&P 500 index, the CRSP AMEX/NYSE equallyweighted return, and Loughran and Ritter (1995) did the CRSP AMEX/NYSE value-weighted return as. 
Each stock's excess return was computed as follows:

Equation \#1: Excess Return from Offer Price

$\mathrm{e}_{\mathrm{it}}=\ln \left[\mathrm{P}_{\mathrm{it}} / \mathrm{P}_{\mathrm{i} 0}\right]-\ln \left[\mathrm{I}_{\mathrm{t}} / \mathrm{I}_{0}\right]$

$P_{i t}$ is the after-market price of stock $i$ at time $t, P_{i 0}$ is the offering price of stock $i, I_{t}$ is the value of the S\&P 500 index at time $t$, and $\mathrm{I}_{0}$ is the index's value on the date that the stock is offered to the public. This was calculated for days $t$ equals from 1 to 8 . The equation is simply the $\log$ ratio of the aftermarket price to the offer price divided by the $\log$ ratio of the S\&P 500 index from the time of offer over the aftermarket period.

Equation \#2: Excess Return Less Day 1 Return

$\mathrm{e}_{\mathrm{it}}=\ln \left[\mathrm{P}_{\mathrm{it}} / \mathrm{P}_{\mathrm{i} 1}\right]-\ln \left[\mathrm{I}_{\mathrm{t}} / \mathrm{I}_{1}\right]$

This is the same equation as Equation \#1, however, each day is compared to Day 1 instead of the offer price to determine the effects of investors purchasing the stock two days following the offer. This was calculated for days 2 through 8 .

Equation \#3: T-test statistic to test $\mathrm{H}_{0}$ : Average Initial Return (ir)=U.S. Historical Average of $15.7 \%$

$$
\mathrm{t}=\frac{\text { average }(\text { ir })-15.7 \%}{\sqrt{\frac{\text { var iance }(\text { ir })}{\text { number.of.sec urities }}}}
$$

Ibbotson et.al. (1994, updated for 1999) found that the average initial return on IPOs in the U.S. between 1960 and 1997 was 15.7 percent. Equation \#3 is used to test whether the average initial return for the 49 companies studied is close to the average.

Equation \#4: Buy and Hold Return

$\mathrm{R}_{\mathrm{iT}}=\left[\prod_{\mathrm{t}=\mathrm{start}}^{\mathrm{min}[\mathrm{T}, \text { delist }]}\left(1+\mathrm{r}_{\mathrm{it}}\right)-1\right] \times 100 \%$

Equation 4 gives the return of each security as an indication of long-run performance. Alternatively, it can be called the percentage buy-and-hold return for firm $i$ at date $T$. Start is the date of the first CRSP-listed closing price after the initial offering, min [T,delist] is the earlier of the last day the stock is listed in the CRSP data as having traded (delisting) or the end of the one-, three-, or five-year period used to measure long-run performance (T), and $r_{i t}$ is the return for stock $i$ on date $t$. The buy-and-hold return is obtained by multiplying each day's return times the next until the last day is reached. Finally the result is converted to a percentage

\subsection{Results}

\subsubsection{Performance in the Aftermarket}


Table 1.1: Mean and Standard Error of Price and Index by Day

\begin{tabular}{|c|c|c|c|c|}
\hline \multirow[b]{2}{*}{ Day } & \multicolumn{2}{|c|}{ Price } & \multicolumn{2}{|c|}{ Index } \\
\hline & Mean & Std Error & Mean & Std Error \\
\hline Offer & 12.75 & 0.71 & 388.48 & 28.90 \\
\hline 1 & 14.34 & 0.90 & 388.15 & 28.99 \\
\hline 2 & 14.30 & 0.91 & 388.95 & 29.21 \\
\hline 3 & 14.24 & 0.92 & 389.06 & 28.21 \\
\hline 4 & 14.10 & 0.92 & 389.43 & 29.33 \\
\hline 5 & 14.05 & 0.93 & 389.25 & 29.14 \\
\hline 6 & 14.00 & 0.93 & 389.07 & 29.08 \\
\hline 7 & 13.98 & 0.92 & 389.12 & 29.09 \\
\hline 8 & 13.88 & 0.93 & 389.50 & 29.22 \\
\hline
\end{tabular}

Table 2: Market-adjusted Performance of 49 IPOs for Up to Eight Daysfor the Period 1971 to 1997

Panel A. Mean Excess Return From Offer Price

\begin{tabular}{||ccccc||}
\hline \multicolumn{5}{|c}{ Panel A. Mean Excess Return From Offer Price } \\
& Mean & Std Error & T statistic & P-value \\
\hline Days from Offer & & & & \\
1 Day & 0.1017 & 0.0174 & 5.8311 & 0.0001 \\
2 Days & 0.0960 & 0.0172 & 5.5741 & 0.0001 \\
3 Days & 0.0904 & 0.0172 & 5.2596 & 0.0001 \\
4 Days & 0.0790 & 0.0178 & 4.4472 & 0.0001 \\
5 Days & 0.0738 & 0.0187 & 3.9361 & 0.0003 \\
6 Days & 0.0694 & 0.0196 & 3.5372 & 0.0009 \\
7 Days & 0.0676 & 0.0204 & 3.3129 & 0.0018 \\
8 Days & 0.0579 & 0.0230 & 2.5131 & 0.0154 \\
\hline
\end{tabular}

Panel B. Mean Excess Return Less Day 1 Return

\begin{tabular}{||lllll||}
\hline & Mean & Std Error & T statistic & P-value \\
\hline Days from Offer & & & & \\
2 Days & -0.0058 & 0.0048 & -1.1975 & 0.2370 \\
3 Days & -0.0113 & 0.0070 & -1.6245 & 0.1108 \\
4 Days & -0.0227 & 0.0092 & -2.4837 & 0.0165 \\
5 Days & -0.0279 & 0.0102 & -2.7468 & 0.0084 \\
6 Days & -0.0323 & 0.0111 & -2.9213 & 0.0053 \\
7 Days & -0.0341 & 0.0120 & -2.8380 & 0.0066 \\
8 Days & -0.0439 & 0.0147 & -2.9850 & 0.0045 \\
\hline
\end{tabular}

Table 1 shows that the mean excess return following the offer jumps dramatically from the offer price to Day 1, then de-clines each day following. On the other hand, the index rises uniformly in the aftermarket, reflecting the current rising market. The underpricing is evidenced by the large jump in the return from the offer to the end of Day one.

Table 2, Panel A indicates that the mean excess return for each day is significantly different from the market index at the 0.0001 significance level for four days following the offer, then it begins to decline from day five through day eight. Panel B of Table 2 examines excess return over the same period, days 1 through 8 , assuming an investment at the end of the first day of trading. When the offer day is excluded, IPO returns in days 2 and 3 are not significantly greater than the market index. However it is negative and increasingly so following the day of offer. This is consistent with the findings of Aggarwal and Rivoli (1990) and Ibbotson, Sindelar, and Ritter (1991).

Figure 1 graphically demonstrates the jump in the price just following the offer, and then demonstrates a gradual decline following day 1. This again demonstrates the underperformance substantiated by previous studies. We also found the average initial return for the companies studied to be 11.38 percent with a t statistic of -2.085 which is statistically different and lower than the U.S. average at a p-value of 0.02 .

\subsubsection{Long-Run Performance}

Table 3 shows the holding period returns for the IPOs over a one-year, three-year, and five-year period as was done in the Loughran and Ritter (1995) paper with IPOs in general. The number of firms $(\mathrm{N})$ included over these periods vary as a result of differing offer dates and whether any firm experienced delisting during the period. The one-year re-turns as much smaller than the 


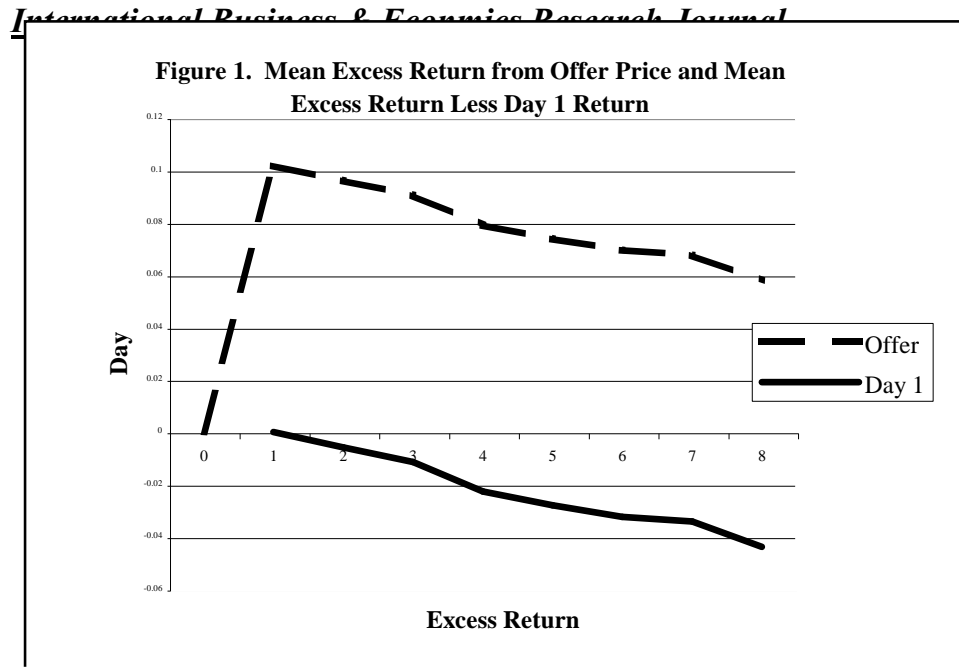

Volume 1, Number 6

three- or five- year return. There is a large variance in the five-year returns.

Table 3.1 shows the returns as compared to three broad market benchmark indices; the CRSP-American Stock Exchange/New York Stock Exchange (AMEX/ NYSE) equally weighted index, the CRSPAMEX/NYSE value-weighted index, and the Standard and Poors 500 (S\&P 500) index. The first column shows the IPO return for each period, and the second column gives the return to the benchmark index. The third column shows the p-value, wherein the test was

Table 3. Holding Period Return Summary Statistics

\begin{tabular}{||cccccc||}
\hline Long-Run Performance & N & Mean & Std Dev & Minimum & Maximum \\
\hline One-year IPO return & 45 & $30.13 \%$ & $9.95 \%$ & $-61.29 \%$ & $247.54 \%$ \\
Three-year IPO return & 33 & $95.41 \%$ & $26.77 \%$ & $-88.54 \%$ & $563.40 \%$ \\
Five-year IPO return & 19 & $214.43 \%$ & $107.84 \%$ & $-97.92 \%$ & $1905.77 \%$ \\
\hline
\end{tabular}

Table 3.1. Average One-Year, Three-Year, And Five-Year Returns And

Wealth Relatives Computed Using Alternative Benchmarks

\begin{tabular}{|c|c|c|c|c|}
\hline & \multicolumn{4}{|c|}{ One-Year Returns } \\
\hline & IPO & Benchmark & T-test & Wealth \\
\hline Benchmark & Return & Return & P-value & Relative \\
\hline CRSP Amex-NYSE EW Index & $30.13 \%$ & $14.65 \%$ & 0.1301 & 1.1476 \\
\hline CRSP Amex-NYSE VW Index & $30.13 \%$ & $30.31 \%$ & 0.9854 & 1.0235 \\
\hline \multirow[t]{3}{*}{ Standard \& Poors' 500} & $30.13 \%$ & $12.31 \%$ & 0.0844 & 1.1733 \\
\hline & \multicolumn{4}{|c|}{ Three-Year Returns } \\
\hline & IPO & Benchmark & T-test & Wealth \\
\hline Benchmark & Return & Return & P-value & Relative \\
\hline CRSP Amex-NYSE EW Index & $95.41 \%$ & $53.31 \%$ & 0.1474 & 1.3441 \\
\hline CRSP Amex-NYSE VW Index & $95.41 \%$ & $137.88 \%$ & 0.0895 & 0.8230 \\
\hline \multirow[t]{3}{*}{ Standard \& Poors' 500} & $95.41 \%$ & $44.87 \%$ & 0.0873 & 1.4514 \\
\hline & \multicolumn{4}{|c|}{ Five-Year Returns } \\
\hline & IPO & Benchmark & T-test & Wealth \\
\hline Benchmark & Return & Return & P-value & Relative \\
\hline CRSP Amex-NYSE EW Index & $214.43 \%$ & $110.20 \%$ & 0.3569 & 1.6075 \\
\hline CRSP Amex-NYSE VW Index & $214.43 \%$ & $299.95 \%$ & 0.4044 & 0.7915 \\
\hline Standard \& Poors' 500 & $214.43 \%$ & $92.67 \%$ & 0.2877 & 1.8172 \\
\hline
\end{tabular}

whether the return to the IPOs was significantly different from the return to the respective benchmark index. The fourth column shows what Loughran and Ritter (1995) refer to as the "wealth relative". This is another way to de- 
termine whether the benchmark index return is larger than the IPO return during the period. The holding period return for the IPO is divided by the holding period return for the benchmark index. This figure is averaged across all firms for each trading day during a year. A value greater than 1 indicates the market outperformed the IPOs based on that benchmark. However, the p-value indicates whether there is a significant difference.

Table 4 shows the holding period returns for all 85 HMOs in the original data set over a one-year, three-

Table 4: Holding Period Return Summary Statistics

\begin{tabular}{||cccccc||}
\hline \hline Long-Run Performance & $\mathrm{N}$ & Mean & Std Dev & Minimum & Maximum \\
\hline & & & & & \\
One-year IPO return & 85 & $23.80 \%$ & $8.15 \%$ & $-85.98 \%$ & $286.75 \%$ \\
Three-year IPO return & 63 & $68.01 \%$ & $17.69 \%$ & $-96.84 \%$ & $563.40 \%$ \\
Five-year IPO return & 44 & $177.48 \%$ & $63.82 \%$ & $-97.92 \%$ & $1905.77 \%$ \\
\hline \hline
\end{tabular}

Table 4.1: Average One-Year, Three-Year, And Five-Year Returns And

Wealth Relatives Computed Using Alternative Benchmarks

\begin{tabular}{|c|c|c|c|c|}
\hline & \multicolumn{4}{|c|}{ One-Year Returns } \\
\hline Benchmark & $\begin{array}{c}\text { IPO } \\
\text { Return }\end{array}$ & $\begin{array}{c}\text { Benchmark } \\
\text { Return }\end{array}$ & $\begin{array}{c}\text { T-test } \\
\text { P-value }\end{array}$ & $\begin{array}{l}\text { Wealth } \\
\text { Relative }\end{array}$ \\
\hline $\begin{array}{l}\text { CRSP Amex-NYSE EW } \\
\text { Index } \\
\text { CRSP Amex-NYSE VW } \\
\text { Index } \\
\text { Standard \& Poors' } 500\end{array}$ & $\begin{array}{l}23.80 \% \\
23.80 \% \\
23.80 \% \\
\end{array}$ & $\begin{array}{c}9.48 \% \\
21.81 \% \\
7.38 \% \\
\end{array}$ & $\begin{array}{l}0.0697 \\
0.7924 \\
0.0398 \\
\end{array}$ & $\begin{array}{l}1.1241 \\
1.0254 \\
1.1485 \\
\end{array}$ \\
\hline Benchmark & $\begin{array}{c}\text { IPO } \\
\text { Return }\end{array}$ & $\begin{array}{c}\text { Benchmark } \\
\text { Return }\end{array}$ & $\begin{array}{c}\text { T-test } \\
\text { P-value }\end{array}$ & $\begin{array}{l}\text { Wealth } \\
\text { Relative }\end{array}$ \\
\hline $\begin{array}{l}\text { CRSP Amex-NYSE EW } \\
\text { Index } \\
\text { CRSP Amex-NYSE VW } \\
\text { Index } \\
\text { Standard \& Poors' } 500\end{array}$ & $\begin{array}{l}68.01 \% \\
68.01 \% \\
68.01 \%\end{array}$ & $\begin{array}{c}46.78 \% \\
123.25 \% \\
37.34 \%\end{array}$ & $\begin{array}{l}0.2419 \\
0.0005 \\
0.0975\end{array}$ & $\begin{array}{l}1.1614 \\
0.7249 \\
1.2649\end{array}$ \\
\hline Benchmark & $\begin{array}{c}\text { IPO } \\
\text { Return }\end{array}$ & $\begin{array}{c}\text { Benchmark } \\
\text { Return }\end{array}$ & $\begin{array}{l}\text { Is } \\
\text { T-test } \\
\text { P-value }\end{array}$ & $\begin{array}{l}\text { Wealth } \\
\text { Relative }\end{array}$ \\
\hline $\begin{array}{l}\text { CRSP Amex-NYSE EW } \\
\text { Index } \\
\text { CRSP Amex-NYSE VW } \\
\text { Index }\end{array}$ & $177.48 \%$ & $\begin{array}{r}94.53 \% \\
274.25 \%\end{array}$ & $\begin{array}{l}0.2027 \\
0.1160\end{array}$ & $\begin{array}{l}1.4599 \\
0.7277\end{array}$ \\
\hline Standard \& Poors' 500 & $177.48 \%$ & $73.67 \%$ & 0.1153 & 1.6863 \\
\hline
\end{tabular}

year, and five-year period. We decided to include those HMOs that did not have an offer price listed in the SDC database since the IPO return data was available in CRSP. This gives a general feel for the long-run performance of all HMOs over the same periods. As indicated in Table 4.1 during all three periods the HMOs outperformed the 
broad market in all but the CRSP-AMEX/NYSE value-weighted index return during years three and four. However, the returns were not statistically significant. Panel B shows that in year three the CRSP-AMEX/NYSE valueweighted index returns out performed the HMOs at a significance level of $8 \%$ which is in keeping with the results in Table 3 for the 49 HMOs

\subsubsection{Comparing Firms Before and After the Stock Market Crash of 1987}

The latter part of the eighties and the nineties saw a wave of mergers of managed care organizations (MCO's) such as HMO's. By merging with other MCO's, these firms would increase coverage with the motive of

TABLE 5. Market-adjusted Performance of 17 IPOs for Up to Eight Days for the Period 1971 to 1986

Panel A. Mean Excess Return From Offer Price

\begin{tabular}{|c|c|c|c|c|}
\hline & Mean & Std Error & T statistic & P-value \\
\hline \multicolumn{5}{|c|}{ Days from Offer } \\
\hline 1 Day & 0.0877 & 0.0328 & 2.6767 & 0.0165 \\
\hline 2 Days & 0.0789 & 0.0328 & 2.4019 & 0.0288 \\
\hline 3 Days & 0.0770 & 0.0335 & 2.2953 & 0.0356 \\
\hline 4 Days & 0.0639 & 0.0355 & 1.7992 & 0.0909 \\
\hline 5 Days & 0.0516 & 0.0326 & 1.5836 & 0.1329 \\
\hline 6 Days & 0.0549 & 0.0326 & 1.6868 & 0.1110 \\
\hline 7 Days & 0.0549 & 0.0357 & 1.5353 & 0.1442 \\
\hline 8 Days & 0.0528 & 0.0377 & 1.4017 & 0.1801 \\
\hline
\end{tabular}

Panel B. Mean Excess Return Less Day 1 Return

\begin{tabular}{|c|c|c|c|c|}
\hline & Mean & Std Error & T statistic & P-value \\
\hline \multicolumn{5}{|c|}{ Days from Offer } \\
\hline 2 Days & -0.0088 & 0.0094 & -0.9366 & 0.3629 \\
\hline 3 Days & -0.0107 & 0.0161 & -0.6680 & 0.5137 \\
\hline 5 Days & -0.0361 & 0.0218 & -1.6540 & 0.1176 \\
\hline 6 Days & -0.0328 & 0.0214 & -1.5313 & 0.1452 \\
\hline 7 Days & -0.0329 & 0.0234 & -1.4046 & 0.1793 \\
\hline
\end{tabular}

getting larger discounts and increasing market power. Using the stock market crash of 1987 as a cutoff point and observing the move toward mergers, the long-run performance before and after this point is evaluated. There was less merger activity before 1987 and more merger activity after 1987 . Among the 49 securities, 17 were pre-1987 and 32 were post-1987. The initial return for the pre-1987 firms was 0.0999 with a p-value of 0.0195 . The 
Table 6. Market-Adjusted Performance Of 32 Ipos For Up To Eight Days For The Period 1988 To 1997

Panel A. Mean Excess Return From Offer Price

\begin{tabular}{|c|c|c|c|c|}
\hline & Mean & Std Error & T statistic & P-valuc \\
\hline \multicolumn{5}{|c|}{ Days from Offer } \\
\hline 1 Day & 0.1092 & 0.0205 & 5.3145 & $<.0001$ \\
\hline 2 Days & 0.1050 & 0.0200 & 5.2566 & $<.0001$ \\
\hline 3 Days & 0.0975 & 0.0197 & 4.9565 & $<.0001$ \\
\hline 4 Days & 0.0870 & 0.0199 & 4.3716 & 0.0001 \\
\hline 5 Days & 0.0856 & 0.0230 & 3.7201 & 0.0008 \\
\hline 6 Days & 0.0771 & 0.0248 & 3.1048 & 0.0040 \\
\hline 7 Days & 0.0744 & 0.0252 & 2.9562 & 0.0059 \\
\hline 8 Days & 0.0606 & 0.0295 & 2.0562 & 0.0483 \\
\hline & Mean & Std Error & T statistic & P-valuc \\
\hline \multicolumn{5}{|c|}{ Days from Offer } \\
\hline 2 Days & -0.0042 & 0.0055 & -0.7515 & 0.4580 \\
\hline 3 Days & -0.0117 & 0.0067 & -1.7409 & 0.0916 \\
\hline 4 Days & -0.0222 & 0.0083 & -2.6796 & 0.0117 \\
\hline 5 Days & -0.0236 & 0.0106 & -2.2216 & 0.0337 \\
\hline 6 Days & -0.0321 & 0.0128 & -2.5011 & 0.0179 \\
\hline 7 Days & -0.0348 & 0.0139 & -2.5068 & 0.0176 \\
\hline 8 Days & -0.0486 & 0.0186 & -2.6081 & 0.0139 \\
\hline
\end{tabular}

Initial return post-1987 was 0.1212 with a p-value less than 0.0001 . Comparing the initial returns for both periods showed no significant difference in returns. Table 5 shows that the excess return from offer price was significant only for Days 1, 2, and 3 pre-1987 while it was significant for all eight days after the offer post-1987 with no significant day differences pre- and post-1987. Conversely, Table 6 shows that the excess return from the Day One return was not significant at all pre-1987 while it was significant only for Days 4, 5, 6, 7, and 8 post-1987, again with no significant day difference pre- and post-1987.

These results are interesting and demonstrate the change in the market before and after 1987. Pre-1987, the returns normalize quickly in the eight days following the offering whereas the post-1987 returns do not normalize and stay relatively high in the eight days following the offering. However, in looking only at the returns less Day 1 for the same periods, the for both pre- 1987 returns do not normalize but stay relatively high throughout the seven day period. The post-1987 returns normalize much more quickly during those seven days. This could demonstrate the markets awareness of the true value of these firms during the early years of conversions. Returns of later conversions would not be as dramatic. 


\subsection{Conclusion}

Previous research examines the returns from initial public offerings of common equity relative to the market index, and finds excess returns to investors who can buy at the offer price. Empirical research also shows that the long-run performance of IPOs under performs the market returns. This research has shown that returns to IPOs of HMOs around the offer day follow a similar pattern. There is an excess return immediately following the offer price that drops quickly in the aftermarket. The excess return appears smaller than historical returns of IPOs.

Long-run performance of HMO-IPOs did not follow the usual behavior of IPO long-run performance as compared to the broad market indices. The HMOs outperformed the market in the first, third, and fifth year for all but the CRSP AMEX/NYSE value-weighted index in years three and five. This may be an indication of the expansion by way of mergers that managed care organizations in general experienced during the 80's and 90's. In examining the pre-and post- 1987 returns, it appears that the market reaction to these conversions was not as dramatic in the post-1987 period as in the pre-1987 period. Areas for future research include investigation of the impact of this expansion. In addition, further research will examine the performance before going public as compared to the performance after going public in cases where accounting data is available.

\subsection{References}

1 Aggarwal, Reena, Ricardo Leal, and Leonardo Hernandez, "The Aftermarket Performance of Initial Public Offerings in Latin America," Financial Management, Spring 1993, pp. 42-53.

2 Aggarwal, Reena and Pietra Rivoli, "Fads in the Initial Public Offering Market?" Financial Management, winter 1990, pp. 45-57.

3 Allen, Franklin and Gerald Faulhaber, "Signaling by Underpricing in the IPO Market," Journal of Financial Economics, 23, 1989, pp. 303 -323.

4 Baron, David, "A Model of the Demand for Investment Banking Advising and Distribution Services for New Issues," The Journal of Finance, 37, No. 4, September 1982, pp. 955-976.

5 Beatty, Randolph P., and Jay R. Ritter, "Investment Banking, Reputation, and the Underpricing of Initial Public Offerings," Journal of Financial Economics. Vol. 15, 1986, pp. 213-232.

6 Bell, J. E., Harry M. Snyder, and Christine C. Tien, "The Public Interest in Conversions of Nonprofit Health Charities," Consumer Union and Milbank Memorial Fund, 1997, p. 8.

7 Brav, Alon, and Paul A. Gompers, "Myth or Reality? The Long-Run Underperformance of Initial Public Offerings: Evidence from Venture and Nonventure Capital-Backed Companies," The Journal of Finance, 1997, 52, pp. 1791-1821.

8 Camerer, C., "Bubbles and Fads in Asset Prices: A Review of Theory and Evidence," Journal of Economic Surveys, March 1989, pp. 3 -4 1.

9 Chalk, Andrew J., and John W. Peavy III, "Initial Public Offerings: Daily Returns, Offering Types and the Price Effect," Financial Analysts Journal, September-October, 1987, pp. 65-69.

10 Claxton, Gary, Judith Feder, David Schactman, and Stuart Altman, "Public Policy Issues in Nonprofit Conversions: An Overview, " Health Affairs, March/April, 1997, p. 9.

11 Datta, Sudip, Mai Iskandar-Datta, and Ajay Patel, "The Pricing of Initial Public Offers of Corporate Straight Debt," The Journal of Finance, 1997, 52, pp. 379-396.

12 DeBont, W. and R. Thaler, "Does the Stock Market Overreact?," Journal of Finance, July 1985, pp. 793-805.

13 Grinblatt, Mark and Chuan-Yang Hwang, "Signaling and the Pricing of New Issues," Journal of Finance, 1989, 44, pp. 393-420.

14 Hogan, Karen and Gerard Olson, "The Relationship Between Firm Size and Returns to IPOs," Villanova University working paper, 1998.

15 Hughes, Patricia, and Anjan V. Thakor, "Litigation Risk, Intermediation, and the Underpricing of Initial Public Offerings,” Review of Financial Studies, 5, 1992, pp. 769-742.

16 Ibbotson, Roger G., Jody Sindelar, and Jay Ritter, "Initial Public Offerings," Journal of Applied Corporate Finance, 7, 1988, pp. 37-45. 
17 Ibbotson, Roger G., Jody Sindelar, and Jay Ritter, "The Market's Problems with the Pricing of Initial Public Offerings," Journal of Applied Corporate Finance, 7, 1994 updated for 1999, pp. 44 -49.

18 Loughran, Tim and Jay R. Ritter. "The New Issues Puzzle." The Journal of Finance, 1, 1995, pp. $23-51$.

19 Mauer, David C., and Lemma W. Senbet, "The Effect of the Secondary Market on the Pricing of Initial Public Offereings: Theory and Evidence," Journal of Financial and Quantitative Analysis, 1992, 27, pp. 55-80.

20 Michaely, Roni, and Wayne H. Shaw, "The Pricing of Initial Public Offerings: Tests of Adverse-selection and Signaling theories," Review of Financial Studies, 1994, 7, pp. 279-319.

21 Miller, Robert E., and Frank K. Reilly, "An Examination of Mispricing, Returns, and Uncertainty for Initial Public Offerings," Financial Management, summer 1987, pp. 33-38.

22 Muscarella, Chris J., and Michael R. Vetsuypens,"A Simple Test of Baron's Model of IPO Underpricing," Journal of Financial Economics, 1989, 24, pp. 125-13.

23 Muscarella, Chris J., "Price Performance of the Initial Public Offerings of Master Limited Partnership Units," Financial Review, 1988, 23, pp. 513-521. Ritter, Jay, “The "Hot Issue” Market of 1980," Journal of Business, 1980, 57, pp. 215-240. Ritter, Jay R. "The Long Run Performance of Initial Public Offerings." The Journal of Finance. 46, No. 1, March 1991, pp. 3-28.

26 Rock, Kevin. "Why New Issues are Underpriced." Journal of Financial Economics,” 15, 1986, pp. 187-212.

27 Rudd, Judith S., "Another View of the Underpricing of Initial Public Offerings", FRBNY Quarterly Review, spring 1991, pp. 83-85.

28 Loderer, Claudio F., Dennis Sheehan, and Gregory B. Kadlec, "The Pricing of Equity Offerings," Journal of Financial Economics, 1991, 29, pp. 35-57.

29 Peavy, John W., III, "Returns on Initial Public Offerings of Closed End Funds," The Review of Financial Studies, 1990, 3, pp. 695-708.

30 Shiller, Ronald, "Do Stock Prices Move too Much to be Justified by Subsequent Changes in Dividends?" American Economic Review, June 198 1, pp. 421-43 6.

31 Tinic, Seha M. "Anatomy of Initial Public Offerings of Common Stock.." The Journal of Finance. 43, No. 4, September 1988, pp. 789-822.

32 Wang, Ko, Su H. Chan, and George W. Gau, "Initial Public Offerings of Equity Securities: Anomalous Evidence Using REITs,” Journal of Financial Economics, 1992, 31, pp. 381-410.

33 Welch, Ivo, "Seasoned Offerings, Imitation Costs, and the Underpricing of Initial Public Offerings," Journal of Finance, 1989, 44, 421-449. 
Notes 